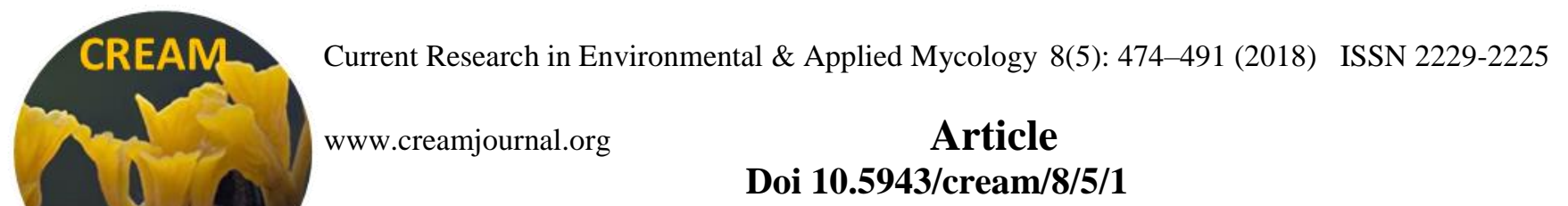

Copyright $(\mathcal{C}$ Beijing Academy of Agriculture and Forestry Sciences

\title{
Sardinia: Mycovisions from a Charming Land
}

\section{Comandini $\mathrm{O}^{1}$, Paulis $\mathrm{S}^{2}$ and Rinaldi $\mathrm{AC}^{1, *}$}

${ }^{1}$ Department of Biomedical Sciences, University of Cagliari, Cittadella Universitaria, I-09042 Monserrato (CA), Italy

${ }^{2}$ Department of History, Cultural and Territorial Heritage, University of Cagliari, Cittadella dei Musei, Piazza Arsenale 1, I-09124 Cagliari, Italy

Comandini O, Paulis S, Rinaldi AC 2018 - Sardinia: Mycovisions from a charming land. Current Research in Environmental \& Applied Mycology 8(5), 474-491, Doi 10.5943/cream/8/5/1

\begin{abstract}
Sardinia is a large island $\left(24.100 \mathrm{~km}^{2}\right.$, the $48^{\text {th }}$ largest in the world $)$ placed in the middle of the Mediterranean basin. Home to extensive sclerophyllous forests and a range of other vegetation types, the island hosts thousands of macrofungi, many of which are linked through ectomycorrhizal (ECM) symbiosis to trees, shrubs and herbs. Despite this rich diversity, however, our knowledge of Sardinian mycota is still superficial, as relatively few studies have been devoted to this topic. One of the reasons behind this lack of interest is probably the traditional mycophoby of Sardinian people, who until recently did collect and consume only a handful of wild edible mushrooms, and used a few more as medical remedies and for other purposes. This article provides a precise account of the current status of knowledge of Sardinia macrofungi, with a special focus on ECM species. We also report on the recent change of attitude of Sardinians towards mushrooms, with their sharp rise in popularity as food, but also as crucial ecological actors, and discuss relevant consequences.
\end{abstract}

Key words - Cistus - ectomycorrhizal fungi - ethnomycology - Halimium - Mediterranean maquis - Quercus - Sardinia - wild edible fungi

\section{Introduction}

\section{The untapped treasure trove of Sardinian mycodiversity}

"And now we touched the verge of the forest, rough with brakes of giant heaths, such underwood alternating with grassy glades wherever the woods opened. This part of the forest consists of an unbroken mass of primitive cork trees of great size. The rugged bark, the strangely-angular growth of the limbs, hung with grey lichens in fantastic combs, and the thick olive-green foliage almost excluding the light of heaven, with the roar of the wind through the trees, for it was a dull, cold day, the coldest we spent in Sardinia, with all this, a Scandinavian forest could not be more dreary and savage. After tracking the gloomy depths of shade for a considerable distance, it was an agreeable change to quit the forest and warm our blood by cantering up a slope of scrub. Then, after crossing a grassy hollow, we came among scattered woods of the most magnificent oaks, both evergreen and deciduous, I ever saw."

With this evocative prose, Thomas Forester renders his feelings while crossing the forests of Barbagia, a mountainous area of inner Sardinia, at the middle of 19th century (Forester 1861). The magnificent woods are still there although they have suffered massive exploitation for prolonged times and they are home to a bewildering variety of mushrooms, both saprobes and ectomycorrhizal 
(ECM). Some estimate this wealth to at least 4000-5000 species (Renato Brotzu, seminar: "Biodiversty of Fungi in Sardinia", October 2012, Cagliari), others push the figures up to 6500 species (Venturella et al. 2011). Just considering aphyllophoraceous fungi, a recent checklist recorded some 412 species belonging to 153 genera (Bernicchia et al. 2008). However, as we will strive to show in this article, much remains to be studied and explored about mycodiversity in Sardinia.

The study of Sardinian mycota has been slow and discontinuous. Until the 70s of last century, only a handful of dedicated works were published. The first reliable data on macromycetes in Sardinia emerged during the 19th century, with the list of 26 species provided by William Barbey (1884) in his Florae Sardoae Compendium. In 1893, Pietro Voglino reported a list of 74 species, mostly from the surroundings of Cagliari, including Amanita caesarea, Cantharellus cibarius and Lactarius deliciosus, without any comments on their edibility or local consume (Voglino 1893). In 1900, Oreste Mattirolo, a famous botanist and mycologist at the University of Turin, published an important contribution to the knowledge of hypogeous macromycetes from Sicily and Sardinia, with a wealth of considerations on the taxonomy, biology and ecology of these fungi (see Fig. 1) (Mattirolo 1900). A small number of other works in the first two decades of the 20th century have expanded the mycological knowledge of Sardinia, but especially for what concerns micromycetes (Belli 1903, 1907, Cao 1903, Saccardo \& Traverso 1903, Mameli-Calvino 1914a, b). To be noted among these studies, the scientific description of Boletus sardous Belli \& Saccardo (= Leccinellum corsicum), one of most common and appreciated ECM mushrooms in the island (Fig. 2) (Belli 1903). "Sul mercato di Cagliari, infatti, esso si vende in gran copia: direi che esso è il più abbondante, od almeno pari, in frequenza, al Pleurotus eryngii DC, detto volgarmente Cardolino de Pessa. Le diverse varietà della Psalliota pratensis e della Psalliota campestris unitamente al Boletus Sardous, ed al Pleurotus Eryngii sopra menzionato, costituiscono la serie di funghi mangerecci permessi sul mercato di Cagliari dall'Ufficio d'igiene," ("In the Cagliari market, in fact, it is sold in abundance: I would say that it is the most abundant, or at least equal in frequency to Pleurotus Eryngii DC, commonly called Cardolino de Pessa. The different varieties of Psalliota pratensis and Psalliota campestris together with the Boletus sardous, and the Pleurotus eryngii mentioned above, are the only edible mushrooms permitted in the Cagliari market by the hygiene inspectorate,") is remarked in a related publication (Belli 1907).

The 'modern era' of mycology in Sardinia takes off in the years 1966-1973, thanks to a series of studies on macromycetes collected in cork oak forests (Quercus suber: Sardinia is one of the main producers of cork in the world, and this product has a considerable economic importance for the region) and other habitats (Valsecchi \& Corrias 1966, Chiappini \& Silecchia 1967, Corrias \& DianaCorrias 1972, Diana-Corrias \& Corrias 1973). Taken together, these surveys quoted over 200 species, of which well over half were new for the mycota of Sardinia. Several noteworthy edible mycorrhizal mushrooms (ECM) associated to cork oak are: Amanita caesarea (Fig. 3), A. rubescens, A. vaginata, Boletus aereus, B. edulis and B. fragrans (= Lamnaoa fragrans), Craterellus cornucopioides, Russula aurora, $R$. cyanoxantha, $R$. delica; and some associated to pine woods are Hydnum repandum, Lactarius sanguifluus and Suillus granulatus.

On the wake of this renaissance of mycological studies, a number of contributions have been published by both Sardinian and non-Sardinian mycologists, covering a wide range of taxa, including the description of several new species (e.g., see De Martis et al. 1983, Contu 2003, 2012, 2013, Padovan \& Contu 2009, Vizzini et al. 2011, Contu \& Vizzini 2013, Ruggero 2014). Among the recent discoveries, a beautiful new variety of Cortinarius cedretorum, described from coastal dunes and linked to Halimium halimifolium, a cistaceous woody shrub, and hence named C. cedretorum var. halimiorum (Brotzu \& Peintner 2009). 

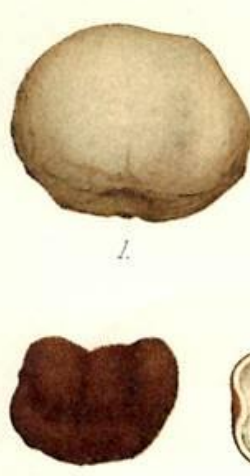

5.

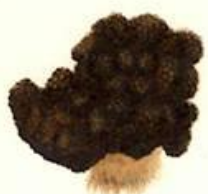

11.
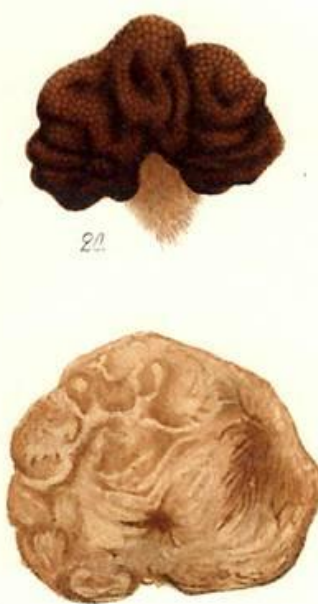

23.

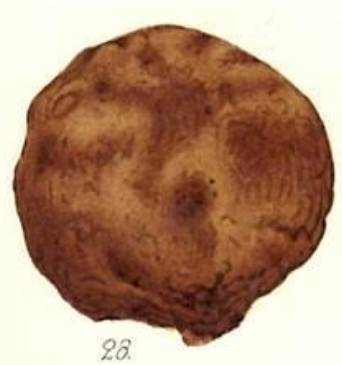

L.Petri dis.
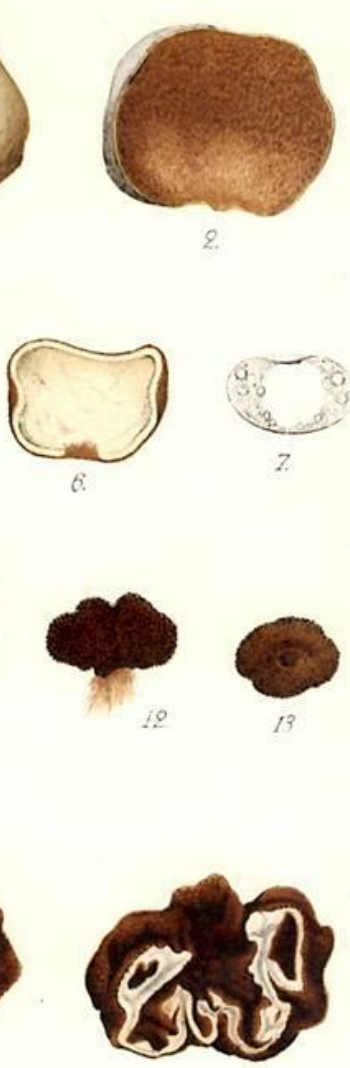

21
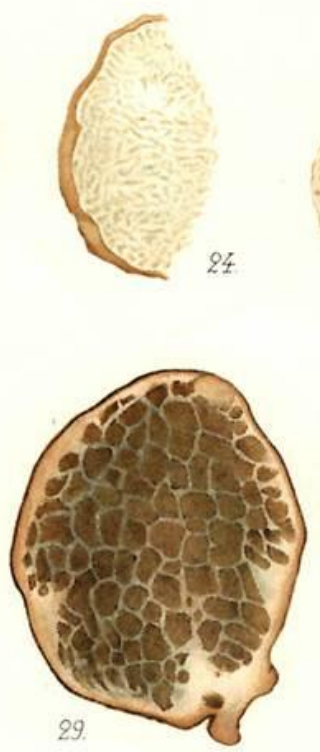

29
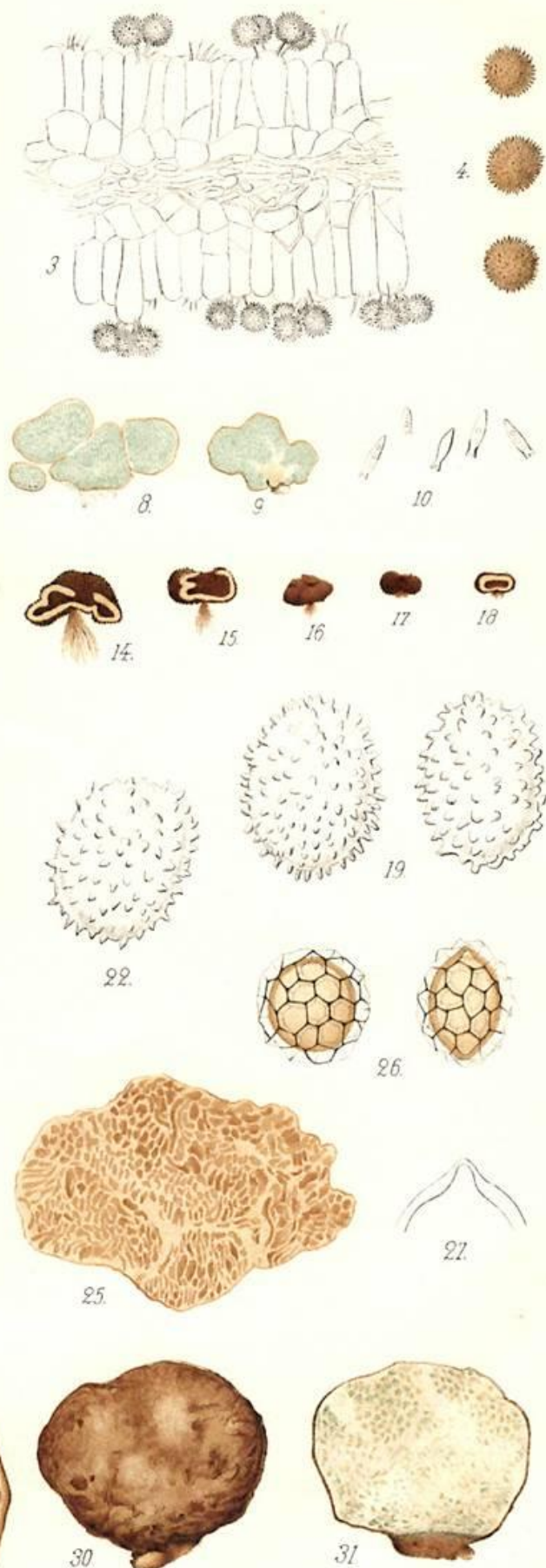

30

firenze, Lit.A.Ruffoni

Fig. 1 - Original table from the seminal work of Mattirolo (1900) on the hypogeous fungi of Sicily and Sardinia. Drawings from 28 to 31 depict Terfezia fanfani, which Mattirolo described in this work on the basis of specimens from Sardinia. 


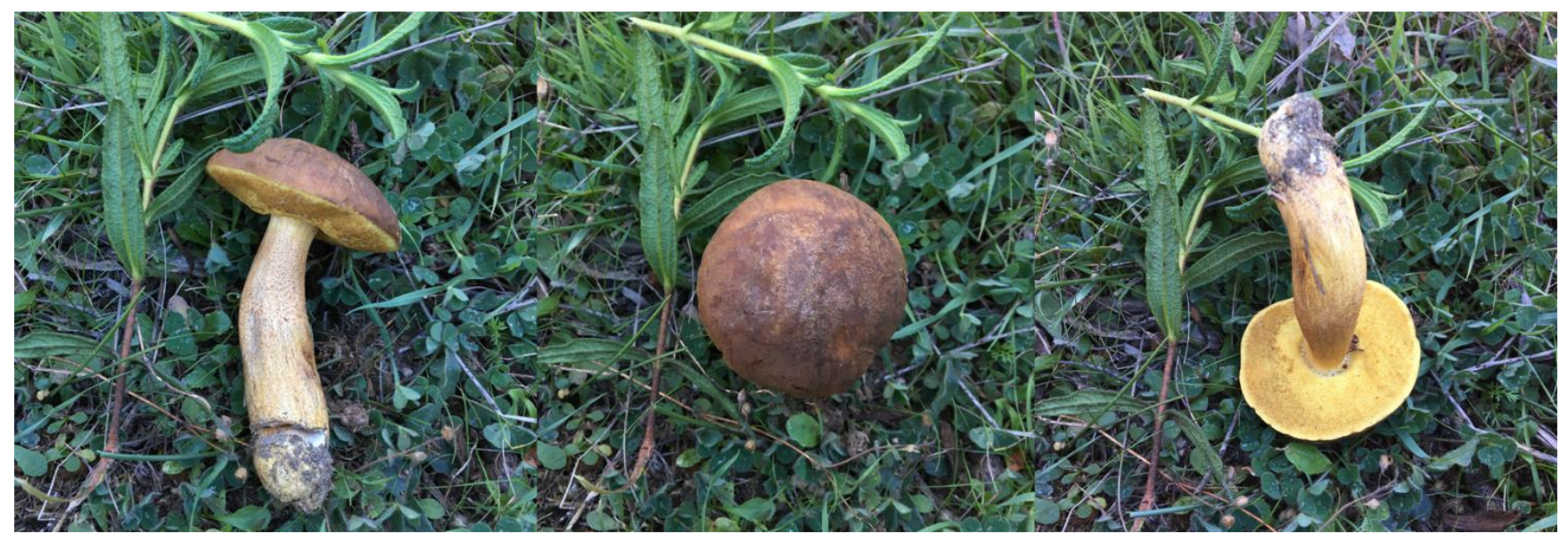

Fig. 2 - The edible and much sought after Leccinellum corsicum (Rolland) Bresinsky \& Manfr. Binder, or cardolinu 'e murdegu. Originally described as Boletus corsicus by Rolland in 1896 and then as Boletus sardous by Belli \& Saccardo in 1903 (Belli 1903). The main diagnostic characters (besides the habitat, strictly linked to Cistus) are clearly visible: cap convex, dark brown to almost blackish; stipe usually stout, pale-yellow to yellow, covered with rusty or brown granules; tubes pale-yellow to yellow, pores concolorous with tubes, sometimes tinged rusty, darkening to somewhat ochraceous when bruised (see http://boletales.com/ for more info).

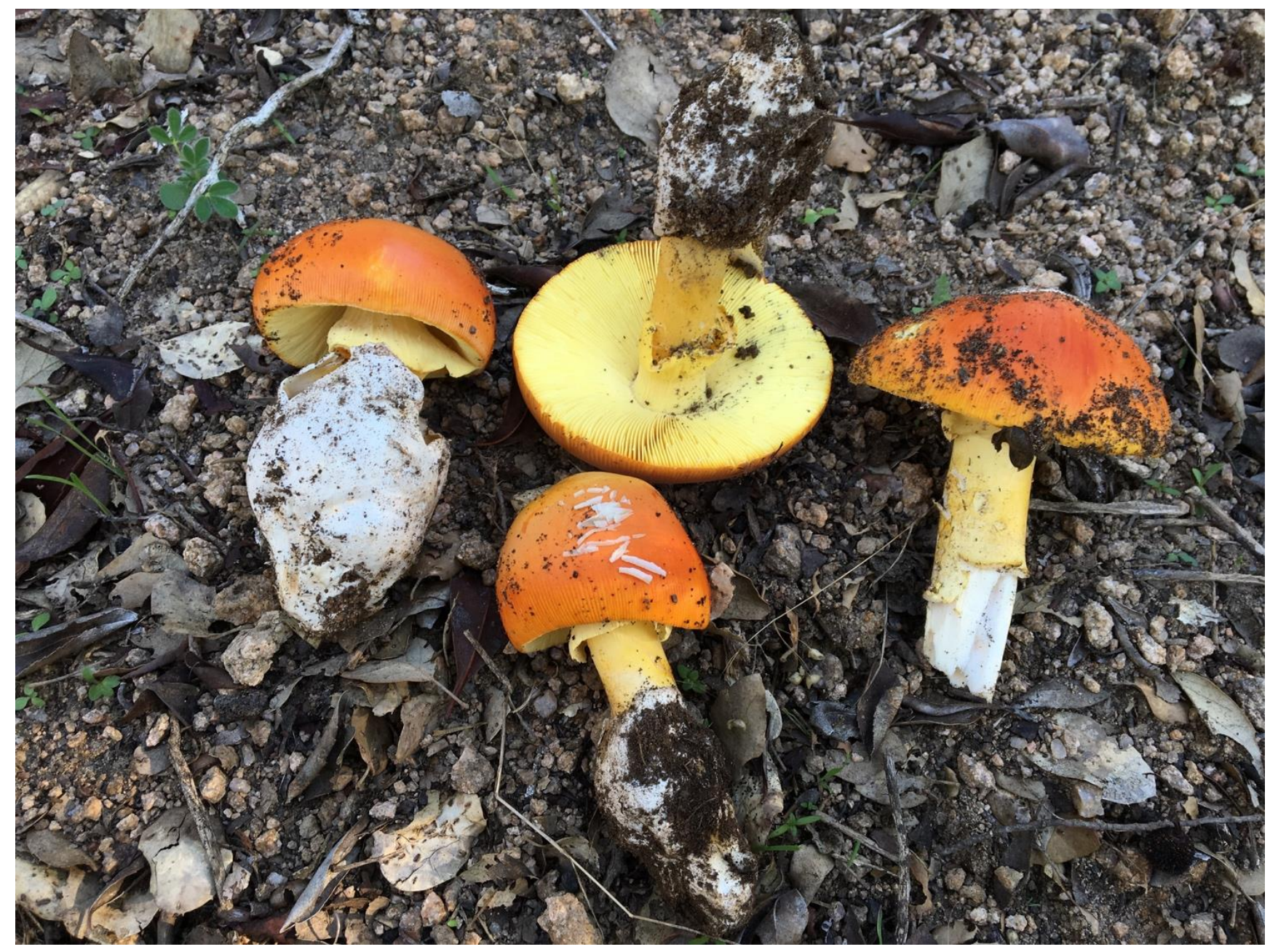

Fig. 3 - Amanita caesarea (Scop.) Pers., one of the best edible ectomycorrhizal mushrooms to be found in the Mediterranean area. These are from a xerophile mixed Quercus ilex-Q. suber forest in Santadi, Cagliari. 


\section{The mycorrhizal landscape of Sardinia}

Due to its position at the center of the western-Mediterranean basin, the climate of Sardinia is typically biseasonal, with hot and dry summers and mild and rainy winters, with two periods (spring and autumn) of intermediate character. Average annual rainfall ranges from less than $500 \mathrm{~mm}$ in the coastal areas to more than $900 \mathrm{~mm}$ in the inner mountainous regions, and mean annual temperature ranges from $11^{\circ} \mathrm{C}$ to $17^{\circ} \mathrm{C}$. Cold and humidity increase proceeding from the sea towards inland, and from the south to the north of the island, while a gradual increase of aridity is noted in opposite direction. The principal formations that characterize Sardinian vegetation include sclerophyllous xerophile and mesophile Quercus ilex and Q. suber forests (Fig. 4). At higher elevations the sclerophyllous oak forests merge with broadleaved forests of $Q$. pubescens (Arrigoni 1968, Bacchetta et al. 2009).

Many of the species of macrofungi mentioned above are ECM (for a list of ECM genera see Rinaldi et al. 2008, Comandini et al. 2012), of course (see for example Fig. 5), but, strangely enough, very few studies have been conducted so far on the characterization of the ECM communities in climax forests in Sardinia. Lancellotti \& Agostini (2013) have surveyed a Q. suber stand in the northwestern sector of the island, with many trees affected by the 'oak decline' disease, a complex interaction of environmental stresses and pests. Mycobionts were identified from ECM tips, through molecular tools and morpho-anatomical observation. Some 57 morphotypes were collected, but only a few were dominant including Cenococcum geophilum, Lactarius chrysorrheus, and some species of Tomentella while most occurred sporadically. Lancellotti \& Agostini (2013) found that the decline class of cork oak trees surveyed did not influence the number of ectomycorrhizal root tips, thus oak decline does not impact the investment in ectomycorrhizal symbiosis. Scattolin et al. (2014) focused on the vitality of root tips and the composition of the ectomycorrhizal community in old-growth $Q$. ilex forests in different areas of Sardinia along an altitudinal gradient. About 48 operative taxonomic units (OTUs) were identified, with C. geophilum being the most abundant species; at the family level, Russulaceae and Cortinariaceae were the most representative taxa. "The results demonstrated that the altitude does not significantly affect the vitality and the degree of ectomycorrhization of the root tips, while significant differences were observed in the ectomycorrhizal community composition, correlated with both the altitude and the Southward exposition of the root systems, both associated to the increase of xeric and drought conditions at the soil level", researchers remarked (Scattolin et al. 2014).

Another cradle of mycorrhizal diversity in Sardinia - and one which has not been studied in detail yet - is Cistus-dominated shrubland that occurs abundantly both along the coasts and in inner areas (Fig. 6). Cistus is a genus of flowering plants in the rockrose family Cistaceae, containing about 20 species of woody, evergreen or semideciduous shrubs. Cistus species are found in wide semi-arid areas from the Canary Islands throughout the Mediterranean basin to the Caucasus, where they are significant components of the maquis and garrigue ecosystems (Ellul et al. 2002, Guzmán et al. 2009). Obligate seeders, Cistus species are early-stage colonizers that follow disturbance, particularly fire, operating in Mediterranean ecosystems. Adaptations include physical seed dormancy, high seed longevity, small seed size and mass, allowing the generation of persistent soil seed banks; the sharp raise in temperature generated in top soil layers by fire breaks seed dormancy and leads to germination (Bastida \& Talavera 2002). Overall, these ecologic characteristics make Cistus mycorrhizal biology particularly interesting.

Indeed, Cistus can form both ectomycorrhizae and arbuscular mycorrhizae, and it has been suggested that mycorrhizal plasticity may represent an important adaptive trait to the cyclical pattern of accumulation and loss of organic resources due to fire (Smith \& Read 1997). As for ectomycorrhizal fungi, an overview of available information has shown that some 230 fungal species belonging to 40 genera of Ascomycota and Basidiomycota have been reported to be associated with Cistus (Comandini et al. 2006). An analysis of the pattern of ectomycorrhizal diversity and hostspecificity revealed that members of the Cortinariaceae and Russulaceae make the most of both Cistus-aspecific and Cistus-specific mycobionts. 


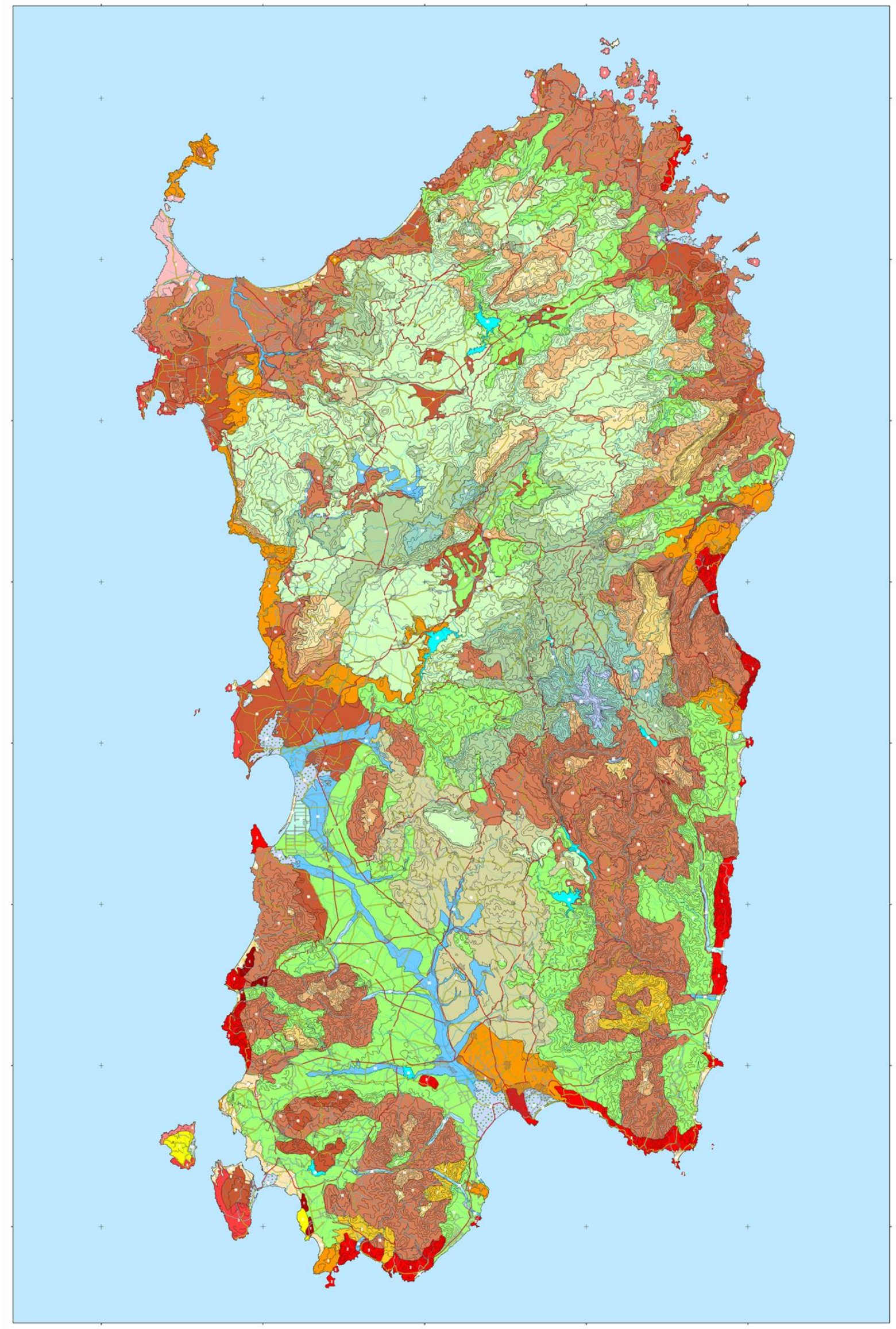

Fig. 4 - Vegetation map of Sardinia. Areas where Quercus ilex and Q. suber forests are prevalent are in brown and shades of light green, respectively. A complete color legend is available at: http://eprints.uniss.it/3544/2/Bacchetta_G_Carta_2009_Carta.pdf 


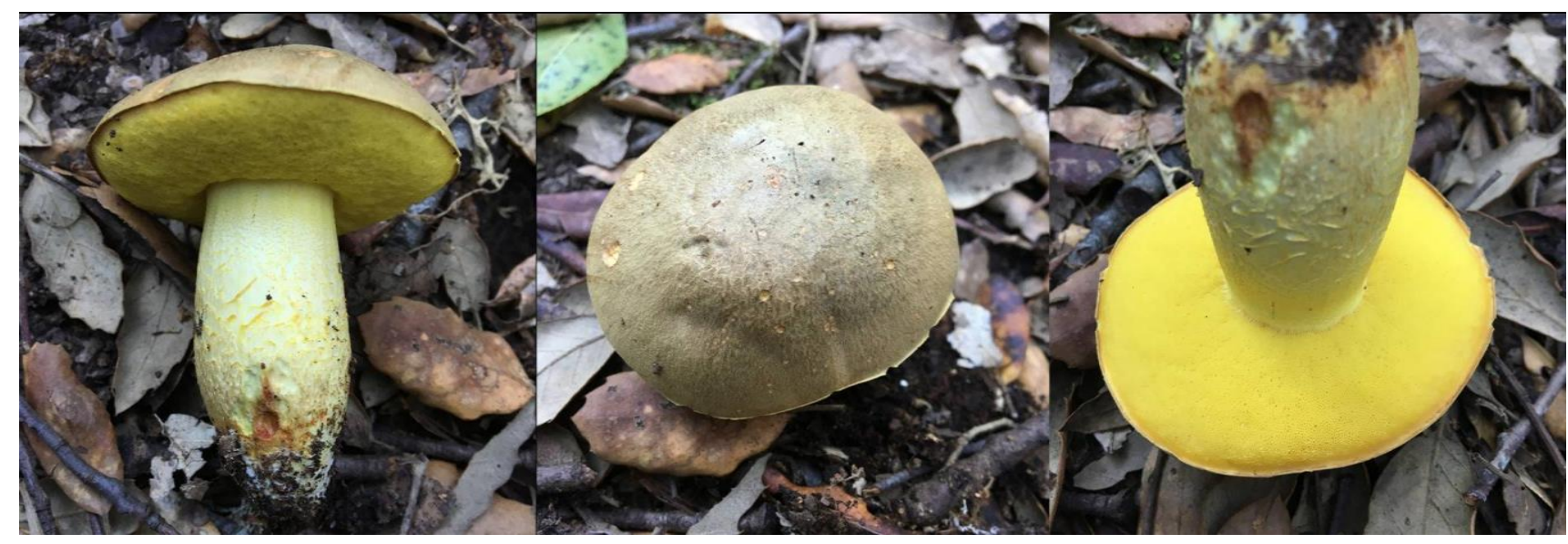

Fig. 5 - Hemileccinum impolitum (Fr.) Šutara (= Boletus impolitus, = Leccinum impolitum). A common, edible species, mycorrhizal with oaks. Cap up to $10 \mathrm{~cm}$, convex to flat-convex, dry, grayish - grayish ochraceous; stipe cylindrical, club-shaped or swollen, cream or pale yellow to yellow, below the tubes often with reddish or rusty band, sometimes yellow orange to red in the base, covered with scattered granules concolorous with the background or darker, unchanging when bruised; tubes pale yellow to yellow with olivaceous tint, unchanging, pores concolorous with the tubes, unchanging when bruised (see http://boletales.com/ for more info).

About 35 Cistus-specific fungi are identifiable to date, all of them being epigeous basidiomycetes occurring also in Sardinia. These include Leccinellum corsicum (see also below), Amanita cistetorum, Hebeloma cistophilum, several Cortinarius species, such as C. subcaninus and C. contui, Hygrophorus pseudodiscoideus var. cistophilus, Lactarius cistophilus, L. tesquorum, Russula cistoadelpha, R. monspeliensis, $R$. tyrrhenica. A second contingent has those fungal species not associated exclusively with Cistus, but rather shared with (or acquired from) other host plants present in the Mediterranean area, such as Quercus and Pinus. Amanita muscaria, Hebeloma hiemale, Laccaria proxima, Lactifluus rugatus and Tuber melanosporum belong to this group (Comandini et al. 2006).

A series of recent studies has extended our knowledge of Cistus mycorrhizal biology, by describing and comparing the ectomycorrhizae formed by Lactarius/Lactifluus mycobionts linked to this host. A total of three milkcap mycorrhizae associated with Cistus, have been described so far: $L$. cistophilus Bon \& Trimbach, member of Lactarius subgenus Piperites sect Uvidi subsect Uvidini (Comandini \& Rinaldi 2008), L. tesquorum Malençon, member of Lactarius subgenus Piperites sect. Piperites subsect. Piperites (Nuytinck et al. 2004), and Lf. rugatus (Leonardi et al. 2016). The structure of these three ECM morphotypes is quite diverse, which makes it possible to easily distinguish them on Cistus roots. Only Lf. rugatus possesses numerous and peculiar cystidia that cover mantle surface; L. cistophilus presents a pseudoparenchymatous outer mantle layer formed by epidermoid cells while L. tesquorum has a plectenchymatous mantle formed by a loose net of hyphae. The three Lactarius/Lactifluus ectomycorrhizae only share the common host-depending ectomycorrhizal features described so far for Cistus, which mainly are small dimensions, small diameter of ectomycorrhizal tips and a quite thin mantle. The diversity of the principal features of the ECMs formed by Lactarius/Lactifluus mycobionts with Cistus reflects the phylogenetic distance between Lf. rugatus, L. cistophilus and L. tesquorum. More in general, this comparative investigation confirmed the informative value of mycorrhizal structure in determining phylogenetic relationships in ECM fungi.

Several other ECM hosts/environments exist is Sardinia that deserve attention but that remain poorly explored. These include riparian vegetation with Alnus glutinosa, Populus spp. and Salix spp., and coastal dune habitats, where ECM cistaceous herbs and shrubs are present (Helianthemum spp., Cistus spp. and H. halimifolium). One of the ECM host plants that certainly deserve attention is Halimium. With the contribution of confocal laser scanning microscopy and molecular tools, we 
recently described the morpho-anatomical features of the ectomycorrhizae formed by Scleroderma meridionale on Halimium halimifolium and collected in Sardinia, the first ECM to be characterized for this genus (Leonardi et al. 2018). A more comprehensive study is currently undergoing in pure stands of $H$. halimifolium in Sardinia, with the goal of exploring the diversity of ECM fungi in these intriguing ecological settings.

Finally, very little attention has been devoted so far to the study of ECM assemblies in the vast areas of Sardinia covered by allochthonous host plants, either introduced in ancient times (e.g., Castanea sativa, Corylus avellana) or used more recently for the various reforestation plans (several species of conifers and Eucaliptus spp.). A recent survey of the macrofungal assembly of a silver fir (Abies alba) plantation in north-west Sardinia, on the Limbara mountain, has recorded the presence of 52 species of Basidiomycota, many of which belonging to ECM genera (Amanita, Hygrophorus, Inocybe, Lactarius, Russula, Suillus, Tricholoma) (Ambrosio et al. 2015; see also Fig. 7 and relevant legend). A previous study in the pure Abies cephalonica artificial forests of the Limbara massif reported a list of 63 macromycetes, many of which ECM, including some edible species such as Amanita rubescens, Lactarius salmonicolor and Boletus edulis (Ruggero \& Contu 2007).

A potentially useful tool for the study of ECM communities in Sardinia and elsewhere, is eMyCo (Lancellotti et al. 2012). An acronym for "EctoMycorrhizal Community", eMyCo is a database developed by researchers at the University of Sassari (Sardinia, Italy) and the University of Bologna, with the aim of gathering information on the structure of ectomycorrhizal fungal communities (http://umi.unibo.it/emyco/index.php). In eMyCo, which currently contains information about 600 ectomycorrhizal species belonging to 13 communities, occurrence of sporocarps in different Mediterranean environments is recorded and mycorrhizae are described using a simplified set of morphological characteristics and by ITS sequences of the symbiotic fungus. According to its description, "eMyCo provides a searchable database that makes it easier and faster to compare among different research projects sharing one or more environmental parameters and/or taxonomic units. This approach provides more exhaustive data about the ecological requirements of an ectomycorrhizal fungal species and its interaction with the others members of a community. Further, eMyCo is able to estimate some ecological indexes of a community to obtain useful information about its structure and diversity and to compare them with those of the other communities" (http://umi.unibo.it/emyco/index.php).

\section{Sardinia and its (recent) mycophily}

"Mushrooms are a prised food in certain regions of the world, but are approached with suspicion in others. For example, there is a long history of collecting and eating wild mushrooms in countries and regions such as Southeast Asia, the Venezuelan Amazon, in Slavic countries and in Italy. The population of these countries are especially fond of mushrooms, and have therefore been labelled as mycophile". This is the incipit of an interesting, recent article by Peintner et al. (2013) about the mycophilic or mycophobic attitude of people in European countries and relevant laws and guidelines released to ensure the safe consumption of wild mushrooms. In such a context, a mycophile person is defined as "one whose hobby is hunting and foraging for wild edible mushrooms", hunting for wild mushrooms also implying their consumption and circulation.

According to this analysis, Italy is one of the European countries were mycophyly is more deeply rooted (Peintner et al. 2013). But is Sardinia Italy? From an ethnomycological point of view and not only from that, certainly not. While in northern Italy the widespread knowledge of wild edible mushrooms and their consumption can be traced back for centuries and more than 250 mushroom species were observed on sale in the market at Trento in modern times (see Peintner et al. 2013), until recently only a handful of species were regularly picked and eaten in Sardinia. This is intriguing, in a land inhabited by an ancient people with a strong agro-pastoral culture and generally believed to possess full knowledge of the natural resources of their environment. "In Sardinia, in past years, around mushrooms it existed a mysterious aura, made of legends and even fears. Poor certainties regarding knowledge of a few fungal species, were matched by a relatively wide world of beliefs and prejudices. Very often all that had the appearance of a mushroom 


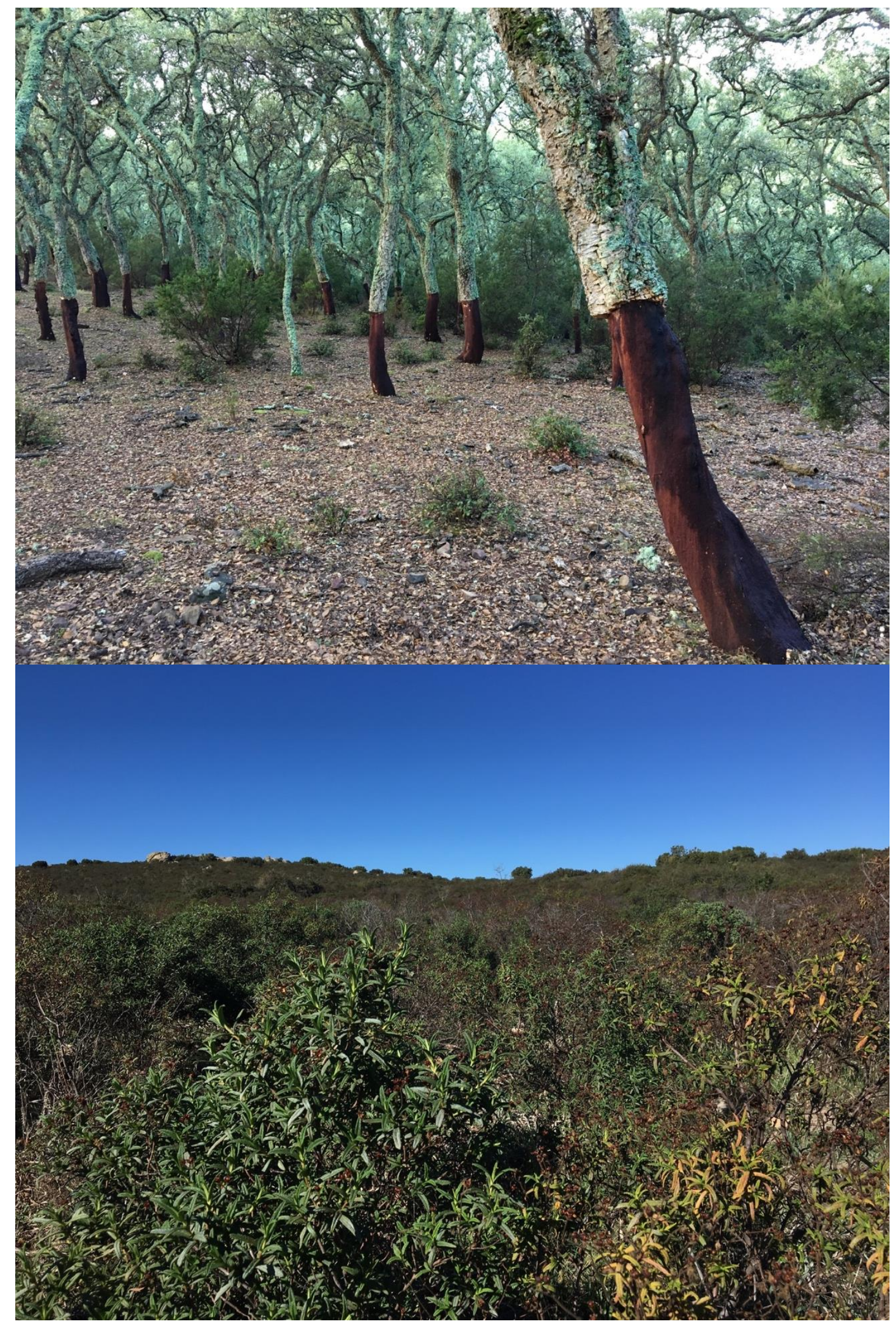

Fig. 6 - Ectomycorrhizal habitats in Sardinia. Above, a Quercus suber (cork oak) forest in the proximity of Iglesias, south-western Sardinia. These are much anthropized woods, where the presence of $Q$. suber has been favoured at the expenses of other co-occurring species, such as $Q$. ilex. Below, Cistus-dominated shrubland in the Sette Fratelli area (south-eastern Sardinia). Cistus creticus, C. monspeliensis and $C$. salvifolius usually co-occur in this type of habitat. 


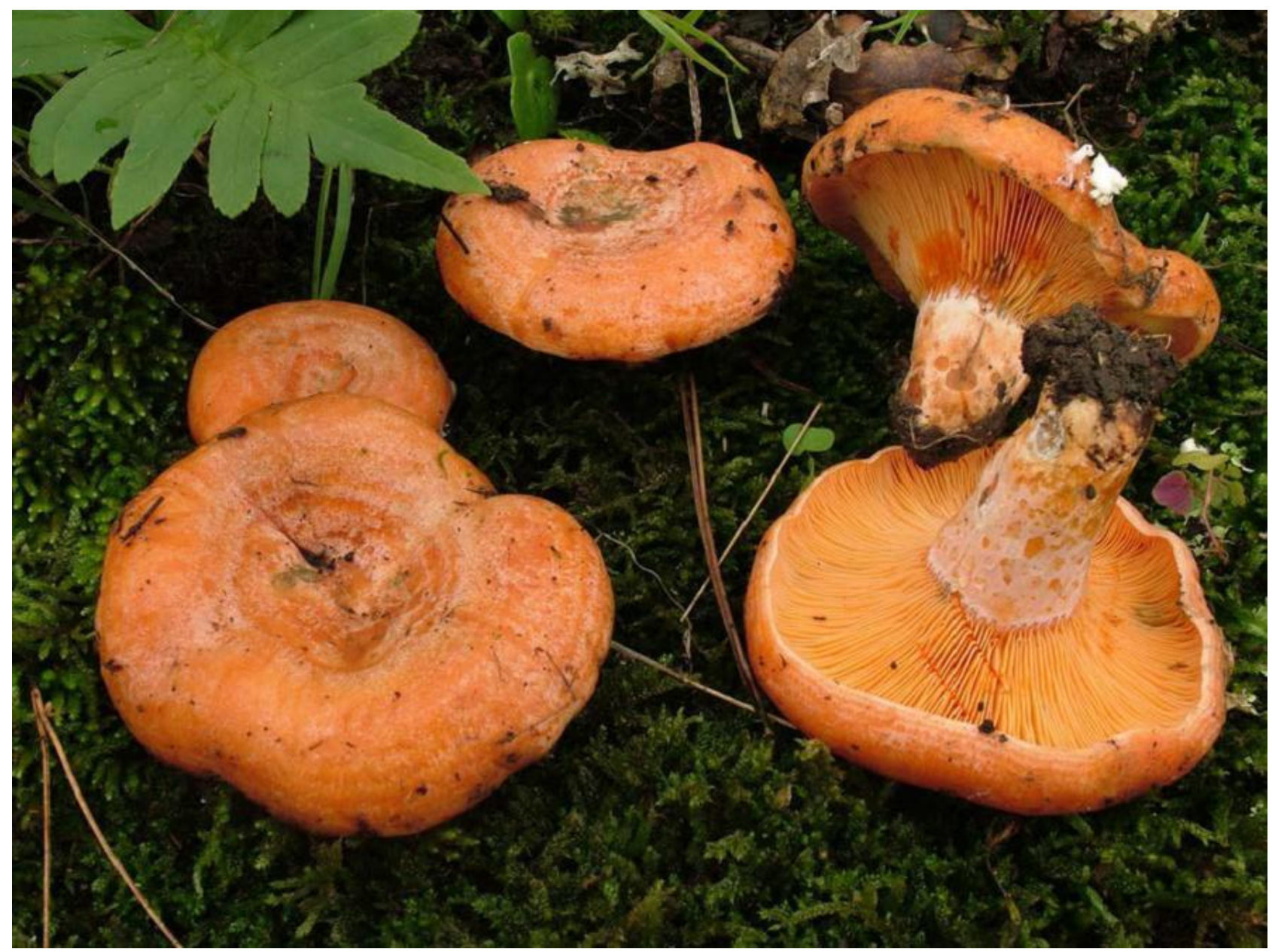

Fig. 7 - Lactarius deliciosus (L.) Gray, the saffron milkcap, an edible and much appreciated species, commonly found under Pinus. In this case, it was curiously reported from a "mono-specific Abies alba plantation", located in north-west Sardinia, on the Limbara mountain (see Ambrosio et al. 2015). In reality, the study site is characterized by the presence of both allochthonous conifers (A. alba, A. cephalonica, Pinus nigra, Cedrus atlantica) and indigenous oak species (Ambrosio et al. 2014). Photo by Renato Brotzu, reproduced under Creative Commons license.

generated apprehension", wrote Sardinian mycologists Brotzu \& Colomo (2009a).

The edible mushrooms traditionally harvested in Sardinia are:

- Pleurotus eryngii (DC.) Quél., a large species of oyster mushroom growing in open fields in association with the roots of Eryngium herbaceous plants, or with Ferula communis (P. eryngii var. ferulae). Known locally as antunna, cardolinu 'e petza, or cordolinu feurrazzu, this is the Sardinia's most appreciated and sought-after edible mushroom (Fig. 8);

- Leccinellum corsicum (Rolland) Bresinsky \& Manfr. Binder (= Leccinum corsicum, = Boletus corsicus, $=$ Boletus sardous, $=$ Leccinum lepidum subsp. sardoum), known as cardolinu 'e murdegu or tunniu 'e mudrecu, a common mycobiont of Cistus spp. (murdegu or mudrecu in Sardinian language) (Fig. 2);

- Terfezia arenaria (Moris) Trappe (= Terfezia leonis), known as tuvara or tuvara de arena. Collected (Fig. 9) mostly in central-western Sardinia (Oristano, Santa Giusta, Terralba, Marrubiu, S. Vero Milis, etc.), this hypogeous mushroom grows in sandy soils, in mycorrhizal symbiosis with the cistaceous Tuberaria guttata (= Helianthemum guttatum) (see http://francosotgiu1.blogspot.it/2012/08/i-funghi-sardi-del-genere-terfezia.html). The consume by locals of this 'false truffle' has been recorded since 19th century (Chatin 1895), and appreciation of its nutritional value dates as back as early 1900s (Cao 1903). Actually, several close species 
(generally referred to as 'desert truffles' in the literature) are collected and consumed, including $T$. arenaria, $T$. claveryi, and T. leptoderma, that are also linked to various species of Helianthemum.

- Macrolepiota procera (Scop.) Singer, widely found in many habitats (both wooded land and open fields) and called tunniu 'e pride, or cappeddu e' pride in local idiom (Fig. 8);

- Agaricus spp., tunniu ruiu, cardulinu ruiu, cucumeddu.

The situation, however, has changed drastically in the last two decades. More and more people nowadays enjoy foraging for wild edible mushrooms, in all areas of Sardinia. Several amateur mycological clubs are now in activity, including one associated with the prestigious Associazione Micologica Bresadola (http://www.ambbresadola.it/), and many of these regularly organize wellattended mycological expositions (Fig. 10). A number of good field guides of common Sardinian mushrooms, with keys to identification of edible species, are now available (e.g., Carcò \& Mendolia 1983, Brotzu \& Colomo, 2007, 2009a, 2009b, Mua \& Casula 2012, Arras 2016). The other side of the medal of this increased popularity of wild mushrooms, is that also the number of intoxications (luckily with very few lethal consequences) due to the ingestion of 'wrong' species is also on the rise. Mycological counselling by certified experts ('ispettori micologici') is available, free of charge, in all major Sardinian cities.

A special note must be added about truffles. Until very recently, it was generally believed that the renowned Tuber species so appreciated worldwide for their taste and pungent aroma were absent from Sardinia. No local knowledge of these hypogeous ascomycetes was ever recorded, and very few mentions were to be found in the mycological literature. But about two decades ago, ascomata of several species, including the black truffle T. melanosporum, started to be collected, especially in the territories of Laconi and Nurallao, central part of the island (T. magnatum, the white Italian truffle, the most expensive edible ECM mushroom, has not yet been found in Sardinia). The ensuing 'truffle craze' has resulted in a considerable expansion of our knowledge about these ECM mushrooms in Sardinia. Brotzu \& Colomo (2009a) quote some eleven Tuber species as present in the island, including T. aestivum, T. borchii, T. brumale and T. melanosporum. Another general account on mycodiversity in Italy has some 41 species of hypogeous fungi present in Sardinia, of which eight species of Tuber (Venturella et al. 2011). The arbutoid mycorrhizas established naturally between $T$. borchii and Arbutus unedo, collected in north-western Sardinia, were described lately (Lancellotti et al. 2014). Truffles, especially the so-called 'bianchetto' (T. borchii), have started to be offered regularly as special treat in local gourmet restaurants. Last year, the first regional truffle association was funded (Associazione Tartufai della Sardegna), with the purpose of promoting awareness about this resource, setting the best practices for truffle collection in the field and educating people to responsible consumption. Another significant effect of this recent interest for truffles and their high economic potential, is that, maybe, under such a pressure, Sardinia could finally succeed in drafting its own legislation on the collection and consume of wild edible mushrooms. Indeed, Sardinia is probably the only region in Italy without guidance lists, another clear indication of the traditional mycophoby (or myco-ignorance) of its population. Of the many bills presented in the last few years to the regional parliament, two merit a mention. The first one, Proposta di Legge n. 104 (27 January 2010; http://consiglio.regione.sardegna.it), lists about 30 species of wild edible mushrooms present in Sardinia that can be commercialized, including A. caesarea, Boletus aereus, B. aestivalis, B. edulis, B. regius, Leccinum duriusculum, L. lepidum, Cantharellus cibarius, Lactarius deliciosus, L. vinosus. The second one, Proposta di Legge n. 34 (16 May 2014; http://consiglio.regione.sardegna.it), focuses on hypogeous mushrooms, setting the rules for the collection of the following species: Elaphomyces anthracinus, Genea fragrans, G. verrucosa, Hymenogaster luteus, $H$. lycoperdineus, $H$. rehsteineri, Melanogaster variegates, Tuber aestivum, T. borchii, T. brumale, T. melanosporum, T. mesentericum, T. oligospermum, T. rufum, Wakefieldia macrospore. For the time being, only local ordinances aimed at ruling on the collection of truffles are enforced.

Intriguingly, in Sardinian tradition, mushrooms represent a resource not only for food. Some species, in fact, were used for therapeutic purposes in the framework of empirical, often nonverbalized (Angioni 1986, Angioni \& Da Re 2003), popular medicine (Atzei et al. 1994, 


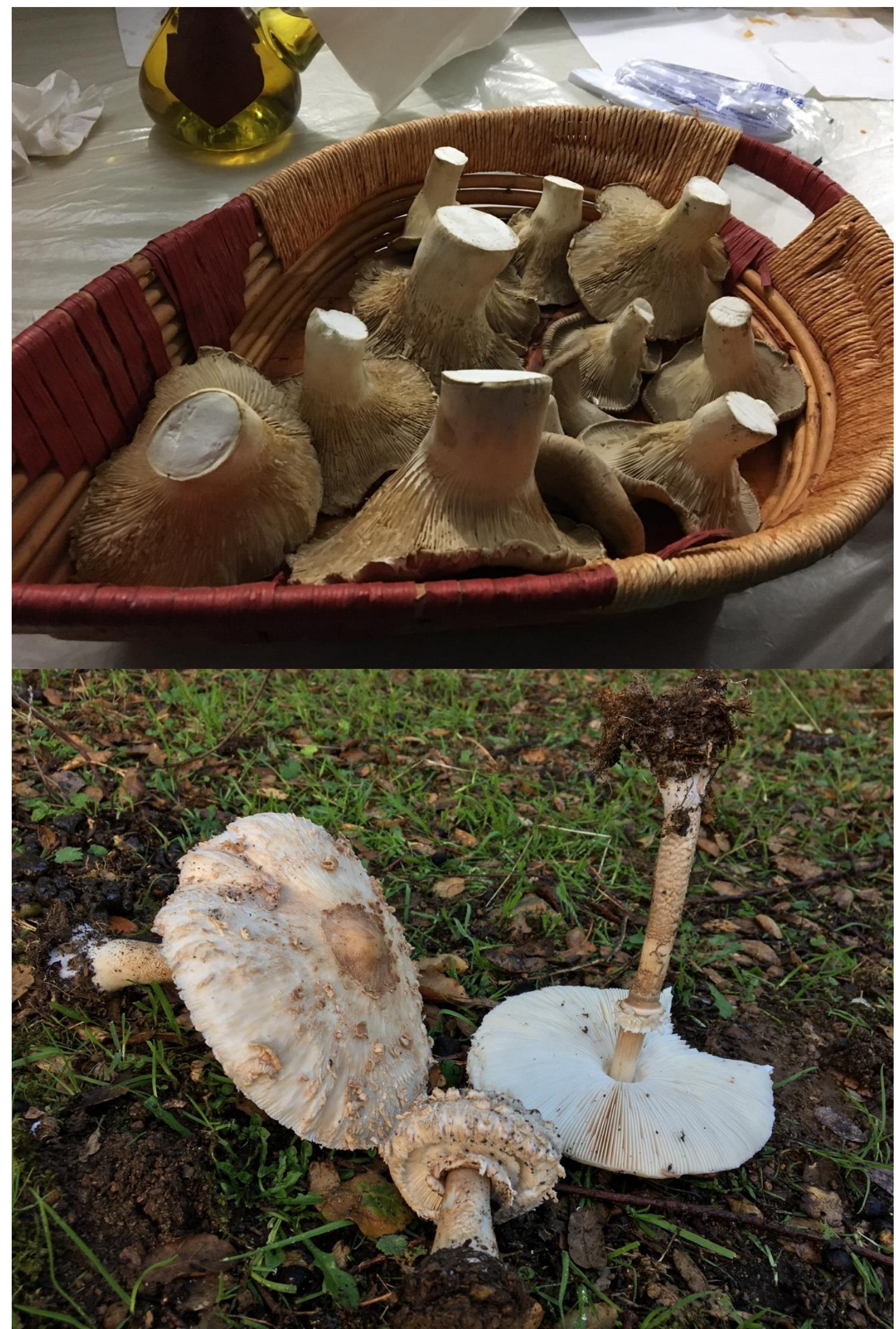

Fig. 8 - Saprobic edible mushrooms in Sardinia. Above, a basket of freshly picked Pleurotus eryngii (DC.) Quél., known locally as antunna, on display at a fair in Settimo S. Pietro, Cagliari. Below, Macrolepiota procera (Scop.) Singer, growing in a Quercus suber (cork oak) forest in the proximity of Iglesias, south-western Sardinia. 


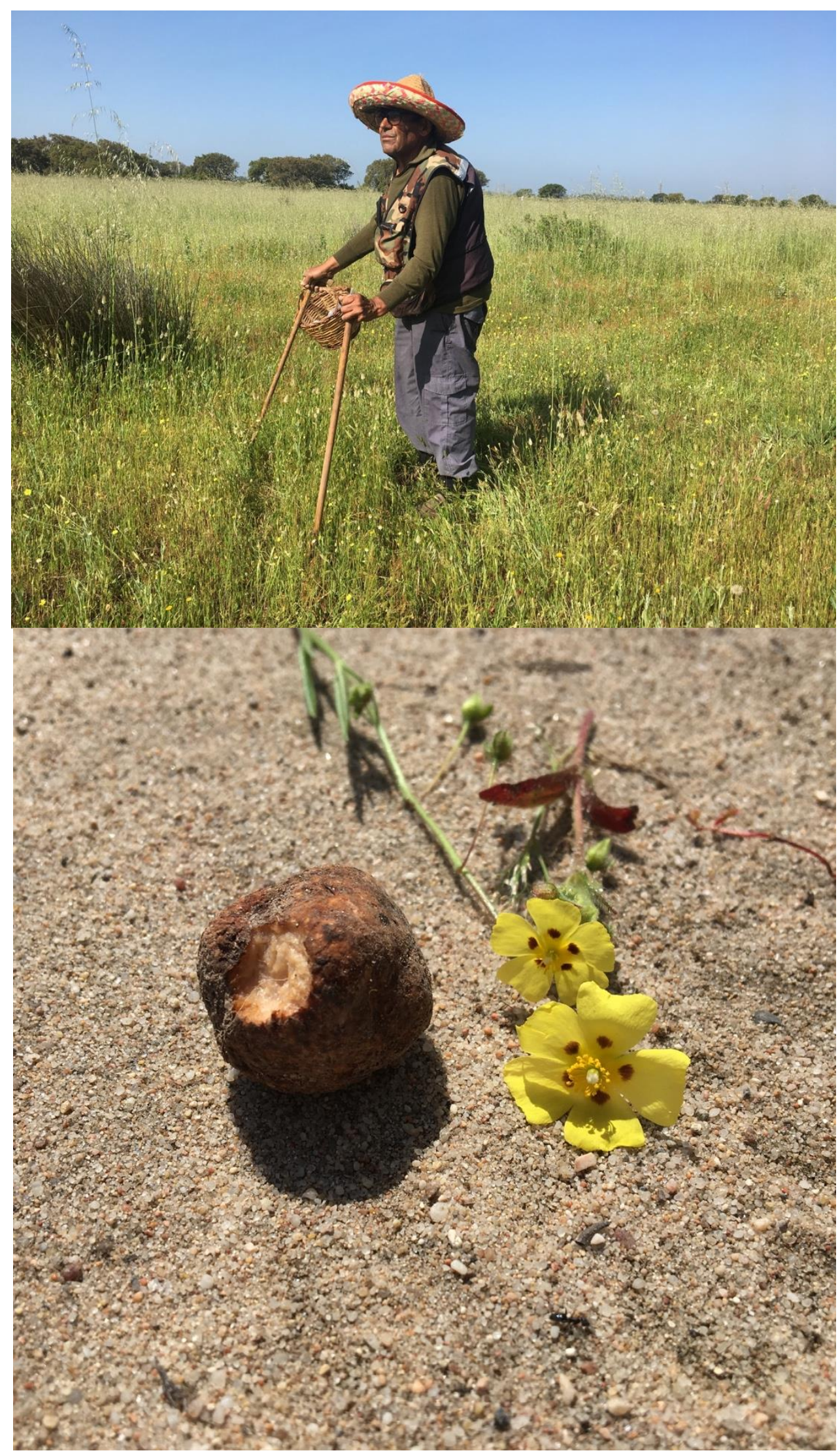

Fig. 9 - Searching for tuvara de arena (Terfezia arenaria) in Santa Giusta, central-western Sardinia. Collectors (above) browse meadows were Tuberaria guttata, the plant host, abounds, probing the sandy, loose soil with the iron point at the end of a stick. After they perceive a discontinuity in the ground signaling the presence of hypogeous carpophores, collectors use the spatula at the other extremity of the stick to carefully dig out the mushrooms (below). 


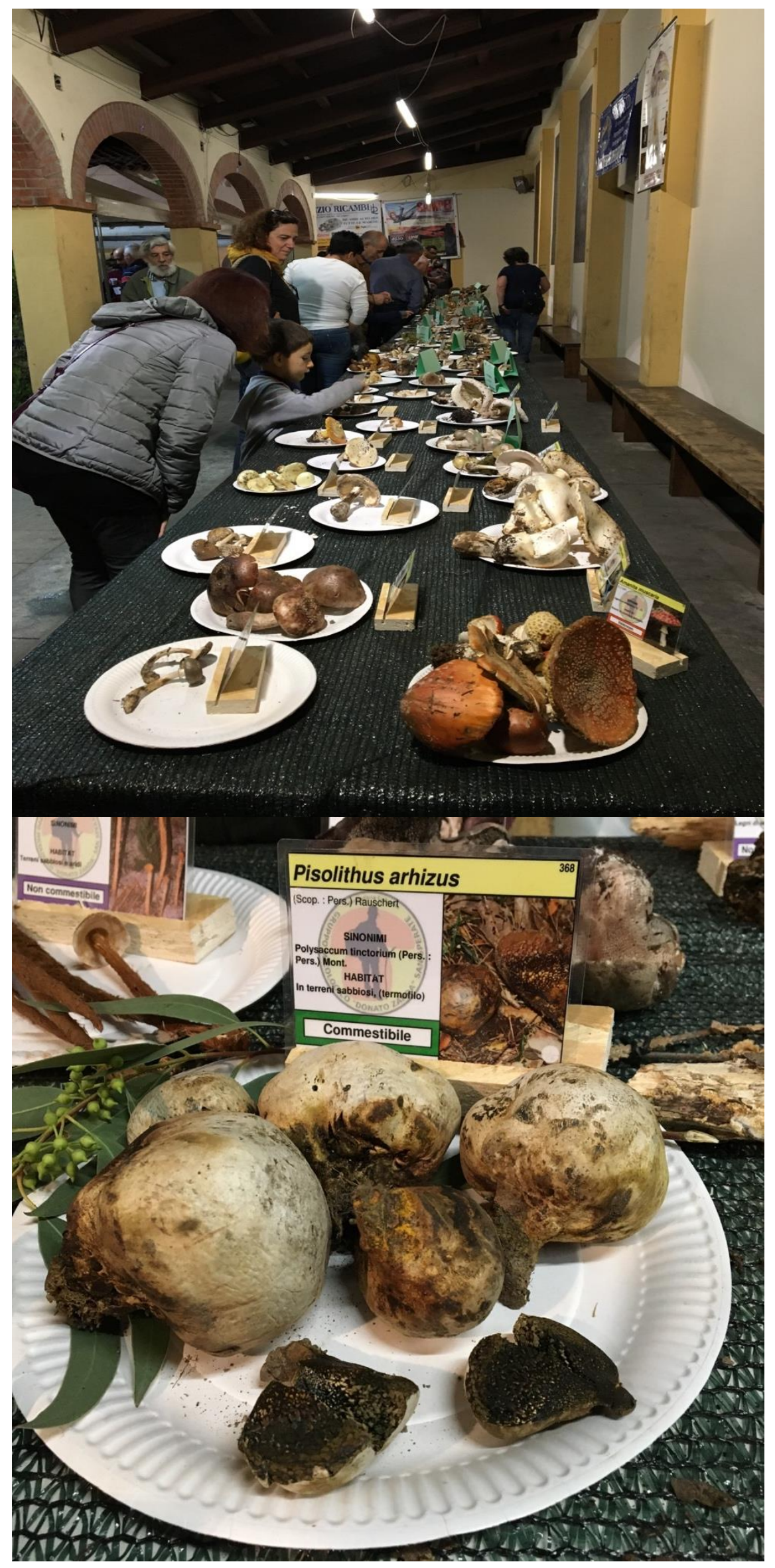

Fig. 10 - Snapshots from a mycological exhibition organized by a local club in San Sperate, Cagliari, November 2016. 
Atzei 2003, Cossu 2005). For example, the tinder fungus, Fomes fomentarius (L.) Fr. which grows in the lower part or in the cavities of the trunk of downy oak, holm oak, or alder, was used to treat wounds with disinfectant, haemostatic and healing functions (Porru Coiana 1955, Brotzu 1993). In Olzai, for example, the mycelium growing on the downy oak (Quercus pubescens), locally called pedde 'e àrvule de kre'u, was applied to the affected part of the lesion and was left until it spontaneously detached from the healed wound. In Seulo, Tonara, Ulassai and in the Oristano area, the same mushroom finds names (peddi àrburi, pedde de àrbure, peddhe 'e matta, peddi de matta) and uses similar to those reported for Olzai (Atzei 2003). In Ulassai the same kind of mushroom is compared to the name of an internal organ of $Q$. ilex (coru de s'iligi: 'heart of the holm oak'; spreni de s'iligi: 'spleen of the holm oak'). To pick it up, still today, the secular plants of the holm oak are split open, and once the mushroom is found, it is preserved with great care, to be then used in small pieces.

The dark powder made up of the dry fruity body of the puffball mushrooms Lycoperdon pyriforme Schaeff. and Lycoperdon perlatum Pers. was used in various parts of Sardinia as haemostatic, disinfectant, or healing remedy, and even as a soothing substance against sunburn. In Carbonia, until recently, it used to make a spore-based ointment with a little olive oil to apply on eczemas and wounds. A particular use of the above-mentioned spores to prevent excessive sweating is known from Oliena. Similarly, in San Vito, the spore powder (called su tabaccu 'e mregiani, 'fox tobacco') was used to treat cases of hyperhidrosis (Atzei 2003). In Gonnosfanadiga it is documented the use of the spores of Bovista plumbea Pers. as a remedy with haemostatic and healing functions (Atzei 2003). Similar uses are reported for Hericium erinaceus (Bull.) Pers., locally known as pèdde mòrta (Ornai) or pèdde kòtta (Sarule) (Atzei 2003). Also Geastrum spp. and Lepista nuda (Bull.) Cooke were used as therapeutics: the former in some parts of the Sassari area (Chiaramonti and Florinas), where the powder contained within the dry mushroom was employed to heal wounds; the latter was rubbed on the joints affected by rheumatic pains.

The main use of $F$. fomentarius, as suggested by its vernacular Italian name "fungo ignario", was that of fire tinder. With this function it was widely used in Sardinia, especially by shepherds and peasants. Not surprisingly, many of the dialectical denominations of this mushrooms (esca, pedde de fogu, peddi fucina, etc.) are inspired by such an use. In Barbagia this mushroom was used in particular by beekeepers to smoke honeybees, so that they could collect honey while forcing bees to swarm elsewhere. Also P. eryngii was utilized as fire tinder.

The aforementioned puffball mushrooms were also used for dyeing purposes. For example, in Villacidro people coloured cheese to simulate the seasoning, dusting it over with the spore powder. The spores powder was also used to dye the cloth and wool brown (e.g. in Nurallao and Perdasdefogu). In Loceri, the same mushrooms, called su fungus piscinu, were deprived of the outer film and squeezed. The liquid so obtained was poured into the water that became coffee-coloured, thus obtaining a solution in which to immerse the clothes worn during mourning.

\section{Conclusions}

As clear to the reader by now, this discussion on the ECM and edible mushrooms of Sardinia has somehow broadened in scope to embrace the story and current status of studies on the entire macromycetous contingent of the Sardinian mycota. What about the future? The potential for sound investigations, whose results might benefit the mycological community at large and well beyond Sardinia, certainly exists, as the biological material is abundant and largely unknown. But do we have the manpower and expertise? The number of professional mycologists at work in Sardinian academic institutions is very small, and dwindling. A single official mycological collection exists, CAG, with over 3000 exsiccata and 113 types (Mulas et al. 2017), but it lacks dedicated and competent personnel, as its curator recently retired. Popular interest in mycology is on the rise, and a number of amateur mycologists are greatly contributing to a more detailed knowledge of the mycota in many of the most valuable habitats of the island. In a perfect world, however, professional and amateur mycologists should work together and support each other, the only realistic manner to tackle more complex taxonomic and ecological studies. On the more practical side, the value of wild edible 
saprobic and ECM mushrooms, including truffles, as an economic resource in Sardinia remains virtually unexplored, and all activities in this thriving sector stem from individual initiatives, without any guidance from regional ruling authorities. Also, the vast possibilities of forestation plans using mycorrhizal plants, with the associated social benefits deriving from the production and harvesting of both mushrooms and truffles with high market values (Zambonelli \& Bonito 2012), remain totally untapped. We vividly hope these few lines will spark some interest in this fascinating mix of related topics.

\section{Acknowledgments}

The authors like to express their gratitude to Davide Puddu, Gruppo Micologico D. Zanda, San Sperate, Cagliari, for introducing one of them (ACR) to the secrets of Terfezia collectors in central Sardinia.

\section{References}

Ambrosio E, Brotzu R, Lancellotti E, Franceschini A, Zotti M. 2014 - Macrofungi in Abies alba Miller plantation in north-western Sardinia, Italy. Micologia Italiana 43, 3-24.

Ambrosio E, Lancellotti E, Brotzu R, Salch H et al. 2015 - Assessment of macrofungal diversity in a Silver Fir plantation in Sardinia (Italy) using a standardized sampling procedure. Micologia Italiana 44, 1-17.

Angioni G. 1986 - Il sapere della mano. Saggi di antropologia del lavoro. Sellerio, Palermo.

Angioni G, Da Re MG. 2003 - Pratiche e saperi e altri saggi di antropologia. Cuec, Cagliari.

Arras L. 2016 - Funghi in Sardegna. Ilisso Edizioni, Nuoro.

Arrigoni PV. 1968 - Fitoclimatologia della Sardegna. Webbia 23: 1-100.

Atzei AD, Orrù L, Putzolu F, Rozzo G, Usala T. 1994 - Le piante nelle terapie tradizionali. Sardegna sud-occidentale. STEF, Cagliari.

Atzei AD. 2003 - Le piante nella tradizione popolare della Sardegna. Carlo Delfino, Sassari.

Bacchetta G, Bagella S, Biondi E, Farris E et al. 2009 - Vegetazione forestale e serie di vegetazione della Sardegna (con rappresentazione cartografica alla scala 1: 350.000). Fitosociologia 46 (Suppl. 1), 3-82.

Barbey W. 1884 - Florae Sardoae Compendium. Catalogue raisonné des végétaux observes dans l'ile de Sardaigne. G. Bridel Éditeur, Lausanne.

Bastida F, Talavera S. 2002 - Temporal and spatial patterns of seed dispersal in two Cistus species (Cistaceae). Annals of Botany 89, 427-434.

Belli S. 1903 - Addenda ad Floram Sardoam. Bullettino della Società Botanica Italiana, 225-226.

Belli S. 1907 - Boletus sardous Belli et Saccardo (n. sp.). Atti della Reale Accademia delle Scienze di Torino 42, 1024-1030.

Bernicchia A, Arras L, Piga A, Ryvarden L. 2008 - Biodiversity of Sardinian Aphyllophoraceous fungi. Synopsis Fungorum 25, 53-124.

Brotzu R. 1993 - Guida ai funghi della Sardegna. Editrice Archivio Fotografico Sardo, Nuoro.

Brotzu R, Colomo S. 2007 - Guida ai funghi della Sardegna. Vols. 1-2. Editrice Archivio Fotografico Sardo, Nuoro.

Brotzu R, Colomo S. 2009a - I funghi della Sardegna. Vols. 1-9. Editrice Archivio Fotografico Sardo, Nuoro.

Brotzu R, Colomo S. 2009b - Guida agli ambienti micologici della Sardegna. Editrice Archivio Fotografico Sardo, Nuoro.

Brotzu R, Peintner U. 2009 - Cortinarius cedretorum var. halimiorum, a new variety of a Phlegmacium associated with Halimium halimifolium (Cistaceae) in Mediterranean costal sand dunes. Bresadoliana 1, 25-44.

Cao G. 1903 - Sul valore alimentare di una tuberacea comune in Sardegna (Terfezia Leonis Tul.). Rivista d'Igiene e Sanità Pubblica 11, 390-403.

Carcò V, Mendolia E. 1983 - Funghi in Sardegna. Editrice Altair, Cagliari. 
Chatin A. 1895 - Terfas du Maroc et de Sardaigne. Bulletin de la Société botanique de France 42, 489-494.

Chiappini M, Silecchia T. 1967 - Basidiomiceti ed Ascomiceti di Sardegna. Nota 1a: Territorio del M. Linas (Iglesiente). Morisia 1, 69-72.

Comandini O, Contu M, Rinaldi AC. 2006 - An overview of Cistus ectomycorrhizal fungi. Mycorrhiza 16, 381-395.

Comandini O, Rinaldi AC. 2008 - Lactarius cistophilus Bon \& Trimbach + Cistus sp. Descriptions of Ectomycorrhizae 11/12, 83-88.

Comandini O, Rinaldi AC, Kuyper TW. 2012 - Measuring and estimating ectomycorrhizal fungal diversity: a continuous challenge. In: Pagano M. (ed). Mycorrhiza: Occurrence in Natural and Restored Environments. Nova Science Publishers, New York.

Contu M. 2003 - Entità rare, critiche o nuove del genere Tricholoma osservate in Sardegna, con segnalazione di due specie nuove per l'isola. Micologia e Vegetazione Mediterranea 18, 91100.

Contu M. 2012 - Appunti sulla flora micologica delle macchie di cisto della Sardegna - XI. Iconografia di Cortinarius cistophilus e prima segnalazione per la Sardegna di Cortinarius assiduus. Micologia e Vegetazione Mediterranea 27, 45-48.

Contu M. 2013 - Appunti sul genere Amanita. XII. Amanita avellanea in Sardegna. Micologia e Vegetazione Mediterranea 28, 3-8.

Contu M, Vizzini A. 2012 - Tephrocybe substriaepilea spec. nov. ed una nuova forma di Tephrocybe baeosperma dalle abetaie montane del massiccio del Limbara (Sardegna). Micologia e Vegetazione Mediterranea 27, 139-144.

Corrias B, Diana-Corrias S. 1972 - Funghi della Sardegna, II. Macromiceti delle sugherete. Memoria n. 34. Stazione Sperimentale del Sughero, Tempio Pausania.

Cossu N. 2005 - A luna calante: vitalità e prospettive della medicina tradizionale in Sardegna. Carlo Delfino, Sassari.

De Martis B, Loi MC, Polo MB. 1983 - Primo contributo alla conoscenza della flora micologica della provincia di Cagliari. Rendiconti del Seminario della Facoltà di Scienze dell'Università di Cagliari 53, 87-97.

Diana-Corrias S, Corrias B. 1973 - Funghi della Sardegna. Macromiceti di ambienti vari. Bollettino della Società Sarda di Scienze Naturali 12, 73-92.

Ellul P, Boscaiu M, Vicente O, Moreno V, Rossello JA. 2002 - Intra- and interspecific variation in DNA content in Cistus (Cistaceae). Annals of Botany 90, 345-351.

Forester T. 1861 - Rambles in the Islands of Corsica and Sardinia with Notices of their History, Antiquities, and Present Condition. 2nd edition. Longman Green Longman and Roberts, London.

Guzmán B, Lledó MD, Vargas P. 2009 - Adaptive radiation in Mediterranean Cistus (Cistaceae). PLOS ONE 4, e6362.

Lancellotti E, Franceschini A. 2013 - Studies on the ectomycorrhizal community in a declining Quercus suber L. stand. Mycorrhiza 23, 533-542.

Lancellotti E, Iotti M, Melis A, Zambonelli A, Franceschini A. 2012 - eMyCo-Ectomycorrhizal community database. IOBC-WPRS Bullettin 76, 133-138.

Lancellotti E, Iotti M, Zambonelli A, Franceschini A. 2014 - Characterization of Tuber borchii and Arbutus unedo mycorrhizas. Mycorrhiza 24, 481-486.

Leonardi M, Comandini O, Rinaldi AC. 2016 - Peering into the Mediterranean black box: Lactifluus rugatus ectomycorrhizae on Cistus. IMA Fungus 7, 275-284.

Leonardi M, Neves MA, Comandini O, Rinaldi AC. 2018 - Scleroderma meridionale ectomycorrhizae on Halimium halimifolium: expanding the Mediterranean symbiotic repertoire. Symbiosis, https://doi.org/10.1007/s13199-018-0548-1.

Mameli-Calvino E. 1914a - Sulla flora micologica della Sardegna. Prima contribuzione. Atti dell'Istituto Botanico dell’Università di Pavia (Serie 2) 13, 153-175. 
Mameli-Calvino E. 1914b - Sulla flora micologica della Sardegna. Seconda contribuzione. Atti dell' Istituto Botanico dell'Università di Pavia (Serie 2) 14, 2-18.

Mattirolo O. 1900 - Gli ipogei di Sardegna e di Sicilia. Malpighia 14, 39-110.

Mulas B, Fogu MC, Puddu D, Tatti A, Cogoni A. 2017 - A census of the mycological herbarium CAG: macromycetes from the Mediterranean area. 112 Congresso Società Botanica Italiana, Parma 20-23 September 2017, abstract book: p. 134.

Mua A, Casula M. 2012 - Atlante dei funghi della Sardegna. Edizioni Grafica del Parteolla, Dolianova.

Nuytinck J, Verbeken A, Leonardi M, Pacioni G et al. 2004 - Characterization of Lactarius tesquorum ectomycorrhizae on Cistus sp., and molecular phylogeny of related European Lactarius taxa. Mycologia 96, 272-282.

Padovan F, Contu M. 2009 - Una nuova specie di Hohenbuehelia stipitata della Sardegna. Bresadoliana 1, 77-82.

Peintner U, Schwarz S, Mešić A, Moreau PA et al. 2013 - Mycophilic or mycophobic? Legislation and guidelines on wild mushroom commerce reveal different consumption behaviour in European countries. PLOS ONE 8, e63926.

Porru Coiana G. 1955 - Della flora officinale della Sardegna. Tipografia La Rinascita, Cagliari.

Rinaldi AC, Comandini O, Kuyper TW. 2008 - Ectomycorrhizal fungal diversity: separating the wheat from the chaff. Fungal Diversity 33, 1-45.

Ruggero A. 2014 - Contributo alla conoscenza della flora micologica del massiccio del Limbara (Gallura, Sardegna Settentrionale). III. Alcune specie rare di notevole interesse fitogeografico. Micologia e Vegetazione Mediterranea 29, 49-58.

Ruggero A, Contu M. 2007 - Contributo alla conoscenza della flora micologica del massiccio del Limbara (Gallura, Sardegna). II. I macromiceti degli impianti artificiali ad Abies cephalonica. Micologia e Vegetazione Mediterranea 22, 53-66.

Saccardo PA, Traverso GB. 1903 - Contribuzione alla Flora micologica della Sardegna. Annales Mycologici 1, 427-444.

Scattolin L, Lancellotti E, Franceschini A, Montecchio L. 2014 - The ectomycorrhizal community in Mediterranean old-growth Quercus ilex forests along an altitudinal gradient. Plant Biosystems 148, 74-82.

Smith SE, Read DJ. 1997 - Mycorrhizal symbiosis. Academic Press, San Diego.

Valsecchi F, Corrias B. 1966 - Funghi della Sardegna. I. Macromiceti delle sugherete. Memoria n. 16. Stazione Sperimentale del Sughero, Tempio Pausania.

Venturella G, Altobelli E, Bernicchia A, Di Piazza S et al. 2011 - Fungal biodiversity and in situ conservation in Italy. Plant Biosystems 145, 950-957.

Vizzini A, Contu M, Musumeci E, Ercole E. 2011 - A new taxon in the Infundibulicybe gibba complex (Basidiomycota, Agaricales, Tricholomataceae) from Sardinia (Italy). Mycologia 103, 203-208.

Voglino P. 1893 - Appunti alla flora micologica della Sardegna. Bullettino della Società Botanica Italiana, 468-476.

Zambonelli A, Bonito GM. 2012(eds) - Edible ectomycorrhizal mushrooms. Current knowledge and future prospects. Soil Biology 34. Springer-Verlag: Berlin Heidelberg. 